\title{
Tectonics
}

\author{
RESEARCH ARTICLE \\ 10.1029/2019TC005586 \\ Key Points: \\ - Costa Rica Osa margin has three \\ across-strike domains based on \\ structural and physical properties \\ - The bulk of the margin is \\ consolidated rock, fronted by a 20 - to \\ 30-km-wide accreted prism \\ - Subducting seamounts correlate \\ with upper-plate strain, \\ overpressure, and earthquakes
}

Supporting Information:

- Supporting Information S1

Correspondence to:

S. Martínez-Loriente,

smartinez@icm.csic.es;

sara.martinez@icrag-centre.org

Citation:

Martínez-Loriente, S., Sallarès, V., R. Ranero, C., B. Ruh, J., Barckhausen, U. Grevemeyer, I., \& Bangs, N. (2019). Influence of incoming plate relief on overriding plate deformation and earthquake nucleation: Cocos Ridge subduction (Costa Rica). Tectonics, 38 . 4360-4377. https://doi.org/10.1029/ 2019TC005586

Received 17 MAR 2019

Accepted 8 NOV 2019

Accepted article online 26 NOV 2019

Published online 18 DEC 2019

(c)2019. American Geophysical Union. All Rights Reserved.

\section{Influence of Incoming Plate Relief on Overriding Plate Deformation and Earthquake Nucleation: Cocos Ridge Subduction (Costa Rica)}

\author{
Sara Martínez-Loriente ${ }^{1,2}$ (D) Valentí Sallarès ${ }^{1}$ (D), César R. Ranero ${ }^{1,3}$, Jonas B. Ruh ${ }^{4}$ (D), \\ Udo Barckhausen $^{5}$, Ingo Grevemeyer ${ }^{6}$ (D) and Nathan Bangs ${ }^{7}$ (D) \\ ${ }^{1}$ Center for Subsurface Imaging, ICM (CSIC) Institute of Marine Sciences, CSIC, Barcelona, Spain, ${ }^{2}$ Irish Centre for \\ Research in Applied Geosciences (iCRAG), School of Earth Sciences, University College, Dublin, UK, ${ }^{3}$ ICREA, Barcelona, \\ Spain, ${ }^{4}$ Structural Geology and Tectonics Group, Geological Institute, Department of Earth Sciences, ETH Zurich, Zurich, \\ Switzerland, ${ }^{5}$ Bundesanstalt fur Geowissenschaften und Rohstoffe (BGR), Hannover, Germany, ${ }^{6}$ GEOMAR-Helmholtz \\ Centre for Ocean Research Kiel, Kiel, Germany, ${ }^{7}$ Institute for Geophysics, University of Texas at Austin, Austin, TX, USA
}

\section{Introduction}

The largest earthquakes occur along the megathrust fault of subduction zones, within the so-called seismogenic zone (Hyndman et al., 1997; Hyndman \& Wang, 1993). The location of the updip and downdip limits of the seismogenic zone vary among subduction zones, reflecting a complex interaction between different factors that control coupling and the transition from stable to unstable slip along subduction megathrusts. Mineral transformations and fluid migration have been suggested to govern the change from aseismic to seismic behavior that occurs across the updip limit of the seismogenic zone (Hyndman \& Wang, 1993; Moore et al., 2007; Ranero et al., 2008), whereas its downdip limit is proposed to be determined by the onset of ductile deformation, largely controlled by the depth of Moho and the thermal structure (Hyndman \& Wang, 1993; Oleskevich et al., 1999; Tichelaar \& Ruff, 1993), which depends in turn on different factors such as the convergence rate, the geometry of the interplate boundary, and the age of the subducting slab. A recent study proposes the existence of 4 domains of seismogenic behavior along the megathrust based on the analysis of tsunami earthquakes, frequencydependent rupture characteristics of recent great earthquakes, and observations of slow slip and tremor phenomena (Lay et al., 2012).

On 16 June 2002, a Mw 6.4 earthquake nucleated $30 \mathrm{~km} \mathrm{NW}$ of the Osa Peninsula, at the southern Costa Rica convergent margin (Figures 1, 2, and S1 in the supporting information). Its focal mechanism solution shows an underthrusting mechanism, suggesting dip slip along the subduction megathrust 


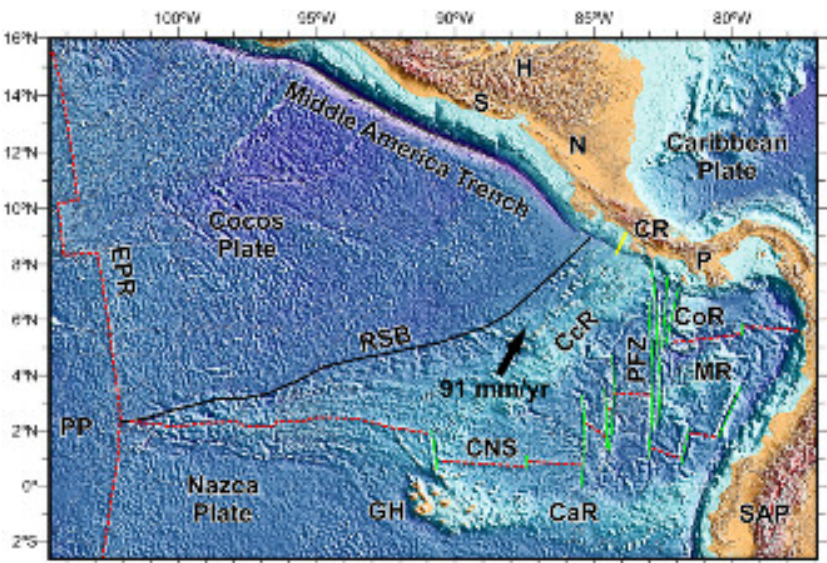

Figure 1. Map of Cocos, Nazca, and Caribbean Plates with their boundaries. Yellow line shows the location of the coincident wide-angle seismic transect and multichannel seismic profile. Red dashed lines display spreading centers. Green lines represent transform faults. Black line labels the RoughSmooth Boundary (RSB). CNS: Cocos-Nazca Spreading center; CaR: Carnegie Ridge; CcR: Cocos Ridge; CoR: Coiba Ridge; CR: Costa Rica; EPR: East Pacific Rise; GH: Galapagos Hotspot; H: Honduras; MR: Malpelo Ridge; N: Nicaragua; P: Panama; PFZ: Panama Fracture Zone; PP: Pacific Plate; S: El Salvador; SAP: South America Plate.
(Arroyo, Grevemeyer, et al., 2014). The Osa earthquake ruptured the northwestern flank of the subducting Cocos Ridge, the volcanic footprint of the Galápagos Hotspot on the Cocos Plate, which rises 2.5 $\mathrm{km}$ above the adjacent basin and is spotted with numerous seamounts (Figures 1, 2, and S1). The main aftershock swarm following the main shock was relocated updip of those of the 1999 Mw 6.9 Quepos earthquake (Arroyo, Grevemeyer, et al., 2014) (Figure S1), which has been interpreted to be associated with the subduction of the Quepos Plateau (DeShon et al., 2003).

The role of subducted seamounts for seismogenesis, and in particular their role as either barriers or asperities for earthquake nucleation and arrest, has been long debated (e.g., Arroyo et al., 2014; Bilek et al., 2003; DeShon et al., 2003; Husen et al., 2002; Mochizuki et al., 2008; Ranero \& von Huene, 2000; Scholz \& Small, 1997; von Huene et al., 2000, 2004). Cloos and Shreve (1996) proposed the "cutting off" scenario, in which the plate boundary zone is viewed as a sediment-filled thick shear zone that thins or thickens arcward depending on subduction speed and trench sediment supply. They suggest that in Chilean-type subducting zones, with thick trench fills and shear zones thinning arcward, tall seamounts are subducted intact to relatively great depths where they hit the overriding rigid block and become seismogenic asperites. In Marianas-type subduction zones, with thin trench fills and shear zones thickening arcward from little inlets, seamounts might be truncated at shallow level near the inlet at low confining pressures generating only small earthquakes. Past the inlet, the seamounts cease being asperites and hence do not generate large earthquakes. Scholz and Small (1997) suggest that significant topographic relief of the subducting plate could increase normal stress and seismic coupling along the plate interface, favoring high-magnitude earthquake nucleation. In contrast, Wang and Bilek (2011) argue that subducting seamounts fracture the upper plate favoring aseismic creep and comparatively smaller earthquakes, inhibiting generation and propagation of large events. Results from 3-D numerical modeling support that subducted seamounts strongly deform the upper plate, generating a severely fractured corridor defined by the width of underthrusting seamounts, resulting in strongly overpressured areas above the leading subducting flank and underpressured above the trailing seamount flank (Ruh et al., 2016).

Here, we present a wide-angle seismic (WAS) transect and a multichannel seismic reflection (MCS) profile along the same across-strike transect that image the southern Costa Rica margin in the area of the Cocos Ridge subduction (Figure 2). The transect crosses the rupture area of the 1999 Quepos and 2002 Osa earthquakes sequences. We combine the Vp model and seismic image of the upper and subducting plates with stress and strain estimations obtained with 3-D numerical modeling of subducting seamounts to investigate (1) the properties and structure of the Cocos Plate and continental margin, (2) the influence of the incoming plate relief on stress and permanent deformation, and (3) the potential role of incoming plate relief on seismogenesis.

\section{Geological Setting}

Along the Pacific Middle America Trench (MAT), the oceanic Cocos Plate subducts underneath the Caribbean plate at $\sim 9 \mathrm{~cm} /$ year (DeMets, 2001) (Figure 1). The Cocos Plate is partly created at the fast-spreading East Pacific Rise and partly at the intermediate Cocos-Nazca Spreading Center that is affected by the Galapagos Hotspot. The boundary between both segments of the plate was called the "Rough-Smooth Boundary" by Hey (1977). Along the margin of Costa Rica, the Cocos Plate displays an along-strike variability in character with three morphotectonic segments (Figures 1 and 2): (1) the Cocos Ridge subducting below the Osa Peninsula and its neighboring continental shelf; (2) the seamount-covered segment subducting at central Costa Rica; and (3) the smooth crust off Nicoya Peninsula (von Huene et al., 2000). Magnetic anomalies show that the age of the Cocos Plate along the MAT varies from 20-25 Ma at the northern smooth segment (generated at the East Pacific Rise) 


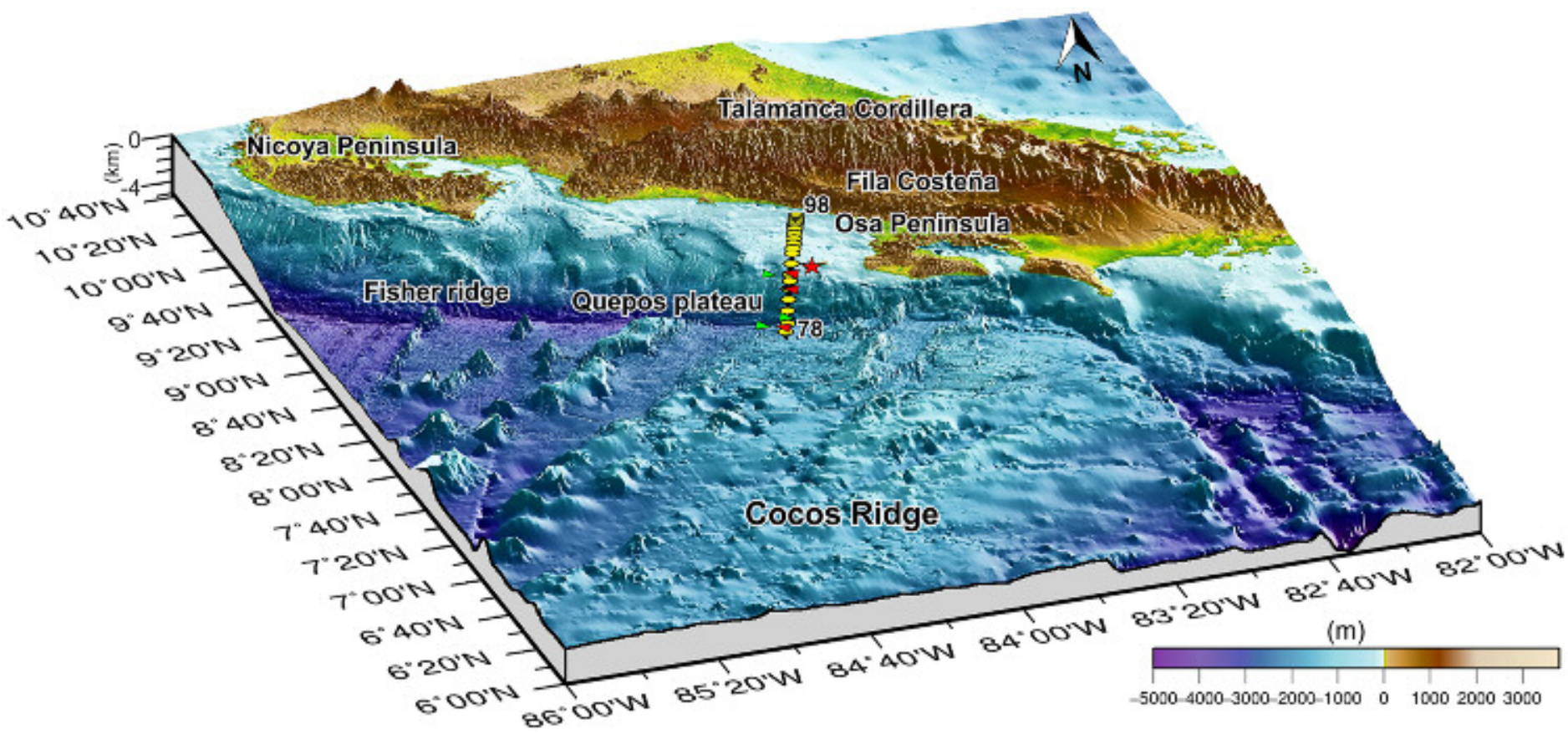

Figure 2. Three-dimensional bathymetric and topographic map of the study area. Black line shows location of the coincident wide-angle seismic transect and multichannel seismic profile. Yellow dots display OBS/Hs deployed along the wide-angle seismic profile. The Integrated Ocean Drilling Program sites at Expeditions 334 and 344 are indicated with red and green triangles, respectively. Red star displays the 2002 Osa earthquake relocated by Arroyo et al. (2014).

to 15-20 Ma at the central seamount-dominated domain and $14 \mathrm{Ma}$ at the Cocos Ridge (both generated at the Cocos-Nazca Spreading Center) (Barckhausen et al., 2001). To the east, the Cocos Plate terminates at the Panama fracture zone that separates it from the Nazca Plate (Figure 1).

The nature and tectonic setting of the Costa Rica margin have been intensely studied during the last decades, and the interpretation of structures and processes that shaped the MAT has changed as techniques and data quality improved. Initially, Costa Rica was proposed to contain a large accretionary prism made of scraped and underplated sediment (e.g., McIntosh et al., 1993; Stoffa et al., 1991), but later, sampling with ODP drilling offshore Nicoya (Kimura et al., 1997) and extensive geophysical data support that the MAT is dominated by tectonic erosion (Ranero et al., 2007; Ranero \& von Huene, 2000; von Huene et al., 2000). The MAT is characterized by long-term subsidence (Ranero et al., 2000; Vannucchi et al., 2003, 2004), supporting large-scale tectonic erosion, although recent 3-D seismic data offshore Osa Peninsula (see location in Figure S1) have shown that the structure may be laterally complex and may locally be characterized by short episodes of accretion and deformation associated to large subducting relief (Bangs et al., 2016; Edwards et al., 2018).

The large-relief features and thick crust of the Cocos Ridge at the trench were originated by the interaction of the Galápagos hotspot with the Cocos-Nazca spreading center at 14 Ma (Werner et al., 1999). The subduction of the Cocos Ridge beneath Costa Rica possibly caused the uplift and exposure of a 135-kmwide zone of the margin, forming the Osa Peninsula (e.g., Kolarsky et al., 1995). The rocks outcropping on Osa Peninsula are a middle Eocene-middle Miocene mélange dominated by basalt, chert, and limestone resulting from accretion of seamounts (Vannucchi et al., 2006). Sak et al. (2004) recognized for the first time the Marenco formation exposed on the northwestern part of Osa Peninsula. These sediments consist of shallow water deposits from late Pleistocene that cut across the Osa mélange basement and record intervals of rapid subsidence and uplift across the Costa Rica forearc. These authors interpret the vertical tectonism recorded by the Marenco formation as the response of the upper plate to variations in the elevation of the subducting Cocos Ridge. In addition, Sak et al. (2004) argued that fracturing and the strain rate related to deformation of the upper plate across the forearc are determined by the magnitude of the orthogonal component of the convergence vector and the bathymetry of the underthrusting plate. Late Pleistocene to Holocene sediment outcrop along the southeastern part of the peninsula and 
has been used to document a net vertical uplift and landward block rotation of the Osa Peninsula (Gardner et al., 1992).

Initially, forearc shortening, regional uplift and cessation of volcanic activity in the Talamanca cordillera in southern Costa Rica were attributed to flat subduction caused by Cocos Ridge buoyancy (e.g., Abratis \& Wörner, 2001; Kolarsky et al., 1995). However, seismological works show that the dip angle of subduction is initially gentle but steepens to normal under the continent (e.g., Arroyo et al., 2003; Dzierma et al., 2011; Lücke \& Arroyo, 2015; Sallarès et al., 2000).

Paleodepth records from samples recovered in southern Costa Rica during Integrated Ocean Drilling Program (IODP) Expedition 334 at Sites U1379 and U1378 (Figure 2) indicate the occurrence of three main tectonic phases in the region (Vannucchi et al., 2012; 2013): (1) a rapid uplift of $\sim 800 \mathrm{~m}$ in the early Pleistocene $(\sim 2.3 \mathrm{Ma})$; (2) a rapid subsidence of $\sim 1,200 \mathrm{~m}$ in the early Pleistocene $(\sim 2.2-1.9$ $\mathrm{Ma}$ ); and (3) a rapid uplift of $\sim 1,000 \mathrm{~m}$ from the middle Pleistocene to Holocene ( 1.9 Ma to present day). Rapid erosion rates have been inferred based on upper plate subsidence and on trench axis retreat, with estimated material removal rates as high as $1,690 \mathrm{~km}^{3} / \mathrm{Myr} / \mathrm{km}$ for the past $0.3 \mathrm{Myr}$ (Vannucchi et al., 2003). These three events have been related to the arrival and underthrusting of the Cocos Ridge in the area, or other bathymetric features (Edwards et al., 2018). Onshore, uplift has been followed by shortening and the formation of the Fila Costeña, a coastal, shallowly rooted, fold-and-thrust belt (Fisher et al., 2004).

\section{Data Set and Methods}

\subsection{WAS Data: Acquisition, Phase Identification, and Modeling}

The 104-km-long TICOSECT Profile 302 was acquired in 1995 onboard the R/V Maurice Ewing using 19 ocean bottom seismometers and hydrophones (OBS/Hs) deployed perpendicular to the margin from the ocean plate to near the coastline (Figure 2). The recording stations included 12 OBSs from the University of Texas Institute for Geophysics), and 7 E-2PD OBHs from GEOMAR (Flueh \& Bialas, 1996). The average receiver spacing is $\sim 5 \mathrm{~km}$, which is about half the distance of most similar experiments. The seismic source used in the experiment was a 20-gun, 138-L (8,420 in. $\left.{ }^{3}\right)$ array towed at 9-m depth and fired at a $24-\mathrm{s}$ interval $(\sim 60 \mathrm{~m})$. Data processing includes predictive deconvolution, frequency band-pass filtering $(2-11 \mathrm{~Hz})$, and automatic gain control amplitude balancing.

The OBS/Hs record sections have a good quality overall (Figure S2). A total of 15,562 picks was manually picked. Seismic phases identified in record sections are multiple and complex and their interpretation has been aided by the coincident seismic reflection profile. The WAS arrivals have been interpreted to correspond to diving waves traveling through the sediments (Ps), the crust of the upper plate (Pg1) and oceanic plate (Pg2), and into the subducting plate upper mantle (Pn); reflections at the base of the sediments (PsP), the interplate boundary (PiP), an upper-lower layers boundary in the basement of the upper plate $(\mathrm{PcP})$, and the subducting plate Moho (PmP) (Figure S2). Additional details on phase identification are provided in the supporting information.

The data set was initially modeled with forward methods and presented by Stavenhagen et al. (1998). Forward modeling is useful for constraining the boundaries between layers but is not able to solve lateral Vp variations. In contrast, the fine mesh applied in the tomographic inversion is better suited to resolve these lateral Vp variations in the short-wavelength structure compared to forward modeling. In this work, we use the joint refraction and reflection traveltime inversion code tomo2d (Korenaga et al., 2000), which allows the simultaneous inversion of traveltimes from first arrivals and from a single reflected phase at a time. Traveltimes and ray paths are computed using a hybrid ray tracing scheme based on the graph method with a local ray bending refinement (Moser et al., 1992). Our model grid is $104 \mathrm{~km}$ long and $33 \mathrm{~km}$ deep, with a node spacing varying in the vertical dimension from $0.025 \mathrm{~km}$ at the seafloor to $0.2 \mathrm{~km}$ at the bottom of the model and a constant spacing of $0.5 \mathrm{~km}$ in the horizontal direction. Node spacing of $0.5 \mathrm{~km}$ for the floating reflector is also uniform along the profile. Details on the different regularization parameters applied to the modeling are presented in supporting information.

We followed a five-step top-to-bottom layer-stripping strategy similar to that described in Martínez-Loriente et al. (2014). It includes (1) traveltime inversion from the sediment phases of the overriding plate alone (Ps 


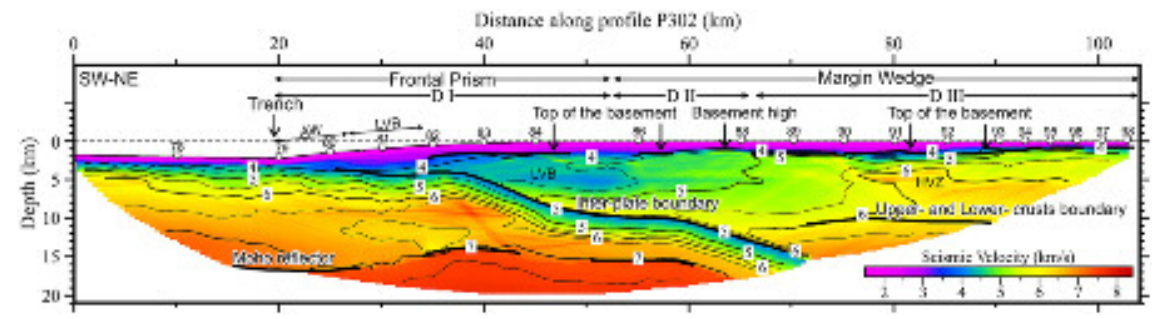

Figure 3. The 2-D final velocity model obtained by joint refraction and reflection traveltime inversion of the whole data set. White circles indicate OBS/Hs locations. Velocity units are km/s. HVZ: high-velocity zone; LVB: low-velocity body; AW: Accretionary wedge; D: Domain. See location in Figure 2. Vertical exaggeration (VE) $\approx 0.75$.

and PsP) to obtain the sediment velocity field and the top of the basement geometry; (2) refracted phases from the upper plate (Pg1), and reflections in the interplate boundary (PiP) to model the velocity field within the upper plate and the geometry of the interplate boundary; (3) all phases traveling within the upper plate (Ps and Pg1) and deep intracrustal reflections (PcP) to resolve the geometry of an intracrustal reflector identified as the upper-lower-crustal boundary; (4) crustal refractions (Pg2) and Moho reflections (PmPs) from the subducting plate; and (5) refractions in the upper mantle (Pn) in order to resolve the structure and geometry of the incoming plate. The details of the initial models used on each step, the damping factors applied, and the initial geometry of each reflector are also included in the supporting information.

The final 2-D velocity model (Figure 3) was obtained after 20 iterations of each of the steps described above. The root-mean-square for the first arrivals (Ps, Pg1, Pg2, and Pn) is $41 \mathrm{~ms}$, whereas it is $53 \mathrm{~ms}$ for the PsP and $\mathrm{PiP}$ reflections and $63 \mathrm{~ms}$ for PcP and $99 \mathrm{~ms}$ for PmPs. The model coverage is represented by the derivative weight sum (Toomey \& Foulger, 1989), which is the column-sum vector of the velocity kernel and provides information on the linear sensitivity of the inversion (Figure S4a). The uncertainty of the inverted model parameters was estimated by applying a statistical, Monte Carlo-type approach. The procedure and outcomes of the analysis are also described in the supporting information (Figure S4b).

\subsection{Multichannel Seismic Reflection Data: Acquisition and Processing}

The 88-km-long MCS BGR99-16B line (Figures 4 and S5), which is coincident with the WAS profile, was acquired in 1999 onboard the R/V Prof. Polshkov. Data were recorded using a 360 channel, 4,500-m-long streamer (i.e., 12.5 group interval) towed at 7-m depth. The source array was towed at 5-m depth and consisted of four subarrays with a total of 40 Sleeve guns and $63 \mathrm{~L}\left(3,800 \mathrm{in}^{3}{ }^{3}\right)$ of total volume fired at 140 bars every $50 \mathrm{~m}$, yielding a 45 common midpoint fold.

MCS processing was performed using Promax and Claritas software packages. The processing flow includes amplitude recovering applying a t2-function, two-window statistical predictive deconvolution, velocity analysis every $5 \mathrm{~km}$, normal moveout correction, near and far offset muting, stack, frequency band-pass filtering following geological structure, finite-differences time migration using a smooth velocity model, and automatic gain control amplitude balancing for display.

\section{Results}

\subsection{Velocity Structure}

The inverted 2-D Vp model (Figure 3) shows a shallow low-Vp layer in the overriding plate that agrees well with the location of sedimentary structures in the seismic image (Figures 4, S5, and S6). Two basins separated by a basement high occur under the continental shelf between 37 and $56 \mathrm{~km}$ and between 67 and 90 $\mathrm{km}$, respectively, with a maximum thickness of $\sim 2.0 \mathrm{~km}$ each. In the southern basin, velocities range from $1.8 \mathrm{~km} / \mathrm{s}$ just below the seafloor to $3.8 \mathrm{~km} / \mathrm{s}$ at its base. In the northern basin, the sedimentary units show velocities ranging between $1.8 \mathrm{~km} / \mathrm{s}$ and $4.5 \mathrm{~km} / \mathrm{s}$. The low-Vp sedimentary layer progressively thins landward to $0.8 \mathrm{~km}$ thick, with velocities ranging between $1.8 \mathrm{~km} / \mathrm{s}$ and $4.0 \mathrm{~km} / \mathrm{s}$. The reflection from the top of the basement agrees well with the $4-\mathrm{km} / \mathrm{s}$ contour, but it is not well resolved between 48 and $66 \mathrm{~km}$ where separation between $\mathrm{OBS} / \mathrm{Hs}$ is larger $(\sim 10 \mathrm{~km})$. From the trench axis to the middle continental slope (20-35 
A)
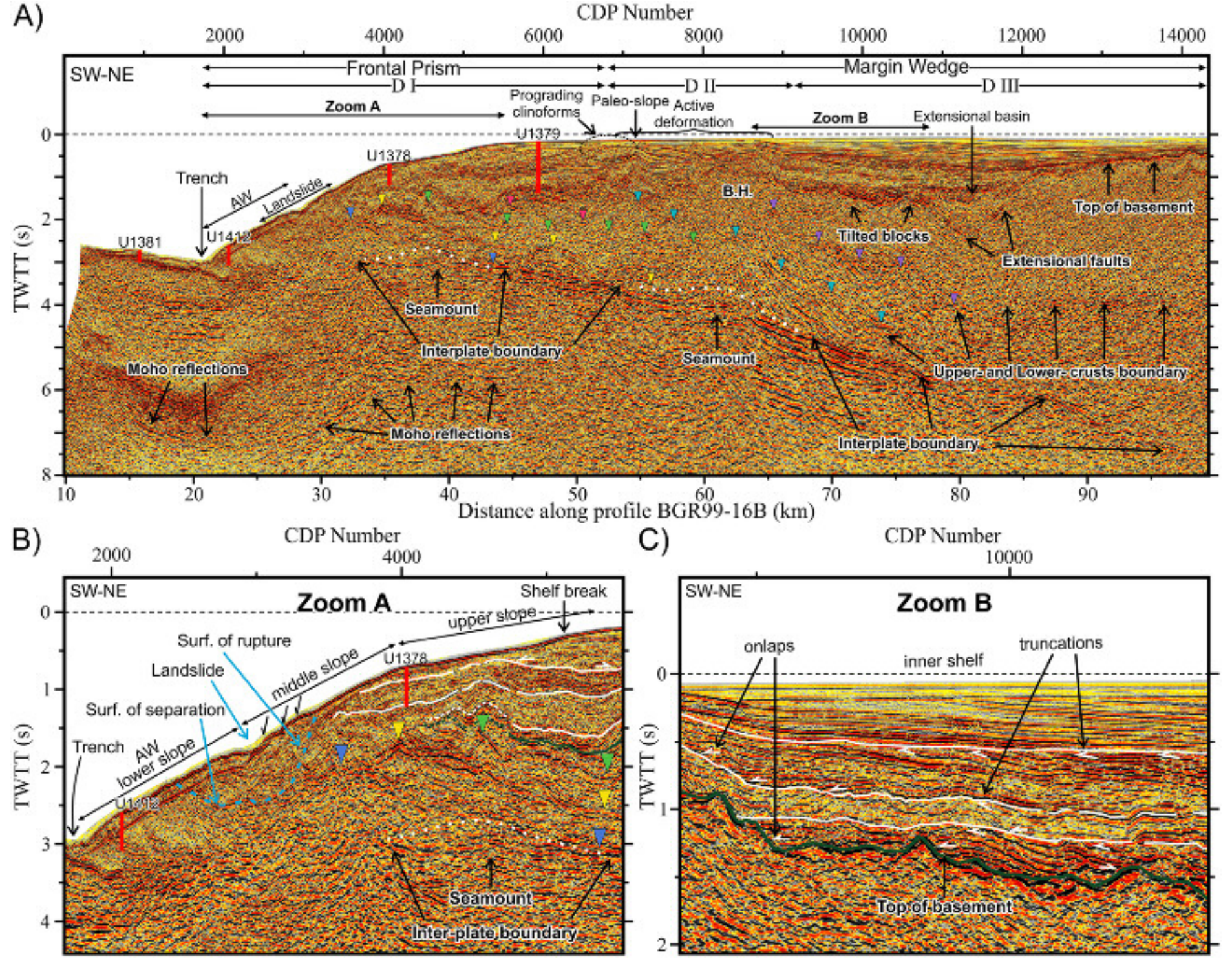

C)

CDP Number

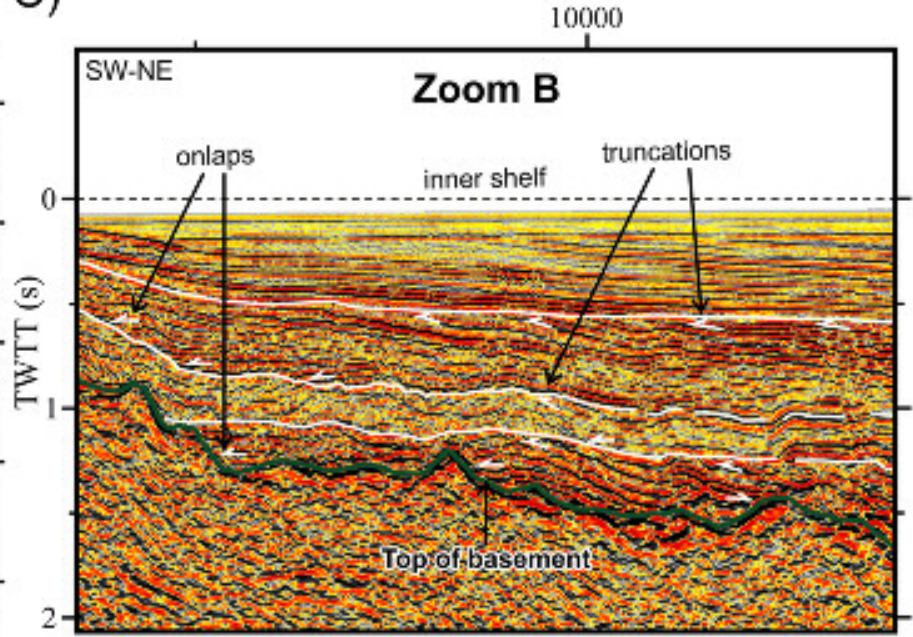

Figure 4. (a) Poststack time migrated MCS BGR99-16B profile acquired coincident with the WAS profile shown in Figure 3. Colored triangles label thrust fault traces. Red rectangles show location of the drill IODP sites projected along the MCS profile (Vannucchi et al., 2003). Seamounts morphology is indicated with white dots. AW: Accretionary wedge; B.H.: Basement High; D: Domain. See location in Figure 2. (b) Close-up of seismic profile showing in detail the imbricated thrust system of Domain I, the unconformities of the sedimentary layer (white lines), the accretionary wedge (AW), the landslide (blue discontinuous lines) and associated normal faults (labeled in black), the shallow seamount (white dots), and reflectivity of the interplate boundary. (c) Close-up of seismic profile displaying the sedimentary sequence (white lines) with the related truncations and onlaps at Domain III, and the high-reflective sediment-basement boundary (green line). VE $\approx 2$.

$\mathrm{km}$ along profile), the top of the basement is less clearly defined. This segment has a complex structure in seismic images (Figures 4, S5, and S6) and a low-velocity body between 27 and $35 \mathrm{~km}$ (Figure 3).

Beneath the sedimentary cover of variable thickness, the overriding plate can be divided into three domains based on abrupt lateral changes in their Vp structure, and tectonic structure shown below. Domain I is the frontal $~ 33-\mathrm{km}$-wide zone of the margin, characterized by a strong lateral velocity gradient with average velocities increasing from $\sim 3.8 \mathrm{~km} / \mathrm{s}$ to $4.5 \mathrm{~km} / \mathrm{s}$. In this domain, the average vertical velocity gradient is $\sim 0.17 \mathrm{~s}^{-1}$ and the horizontal gradient is $\sim 0.02 \mathrm{~s}^{-1}$. Domain II is a $15-\mathrm{km}$-wide transition zone were average velocities increase horizontally from 4.5 to $5.0 \mathrm{~km} / \mathrm{s}$, and vertically from 4.0 to $5.5 \mathrm{~km} / \mathrm{s}$. Domain III does not have the bottom determined along the entire line. Domain III basement thickens from $\sim 9 \mathrm{~km}$ thick to more $\sim 15 \mathrm{~km}$ thick in the frontal $\sim 10 \mathrm{~km}$, and it is $>40$-km-wide forming the bulk of the upper plate. The basement 
Vp increases horizontally from 5.0 up to $6.5 \mathrm{~km} / \mathrm{s}$ and vertically from 4.0 up to $6.5 \mathrm{~km} / \mathrm{s}$ (Figure 3). Within Domain III, there is a relatively high-velocity body with velocities up to $6.3 \mathrm{~km} / \mathrm{s}$ at $\sim 5 \mathrm{~km}$ underneath the seafloor. An intrabasement reflector at $\sim 10-\mathrm{km}$ depth bounds at the top a basement segment with $6.5 \mathrm{~km} / \mathrm{s}$ $\mathrm{Vp}$ on average, typical of both oceanic and continental lower crust. The geometry of the interplate bounding reflector, with $12^{\circ}$ average dip, is well imaged by PiP phases. The plate boundary reflector is irregular and shows prominent relief reflecting the rough topography of the incoming plate (Figure 3).

The incoming and subducting plate presents a laterally varying oceanic-like velocity structure, with a crustal thickness decreasing from 13-14 km under the trench axis to 6-7 km thick below the continental shelf (Figure 3). Velocity of the upper 1.0-1.5 km ranges between 2.2 and $3.5 \mathrm{~km} / \mathrm{s}$ underlain by a steep vertical velocity gradient of $0.65 \mathrm{~s}^{-1}$, with velocities ranging from $3.5 \mathrm{~km} / \mathrm{s}$ at the top to $\sim 6.5 \mathrm{~km} / \mathrm{s}$ at the bottom, typical of upper oceanic crust or Layer 2 (Grevemeyer et al., 2018 and references therein). The thickness of this layer is rather uniform $(3.5 \pm 0.5 \mathrm{~km})$, but much thicker than for normal oceanic crust (Grevemeyer et al., 2018). Lower crust or Layer 3 thickness ranges from $9 \mathrm{~km}$ under the trench axis to $3-4 \mathrm{~km}$ below the continental shelf; thus, like for any hot spot-affected crust, its thickness is increased. Layer 3 Vp is laterally uniform, ranging from $\sim 6.5 \mathrm{~km} / \mathrm{s}$ at the top to $7.2-7.3 \mathrm{~km} / \mathrm{s}$ at its bottom, just above the Moho. Convex-up relief of the interplate geometry between 33 and $42 \mathrm{~km}$ and around $\mathrm{km} 57$ are underlain by the strongest vertical Vp gradients (Figure 3). The shallow feature coincides with a change in seafloor dip at the upper slope between OBS/Hs 82 and 84 . The base of oceanic Layer 3 is marked by three segments of Moho PmP reflections (Figures 3 and S4). Under the crust-mantle reflector, velocity ranges from 7.0 to $7.8 \mathrm{~km} / \mathrm{s}$, which appears to be low velocity for upper mantle.

\subsection{Tectonic Structure}

The MCS BGR99-16B profile (Figure 4), coincident with the WAS transect (Figure 3), provides information on the stratigraphy and tectonic structure of overriding and subducting plates. The Vp model and the seismic image provide information for an integrated interpretation of features in both data sets. There is a good general agreement between geological boundaries in MCS images and the inverted ones using WAS reflections. The boundaries that are well mapped in both data sets are the base of the sedimentary cover and the interplate boundary, whereas the intrabasement reflector in the overriding plate and the Moho of the subducting plate are indistinct in the MCS images and have been first defined in the Vp model. In the MCS profile, Domain I includes an 8-km-wide imbricated sediment frontal prism abutting a larger body with stratal architecture in an imbricated structure of thrust sheet faulting and folding that coincides with a lateral increase in Vp (Figures 4a and 4b). Domain II displays a transitional zone with landward dipping reflections, possibly sheets of indurated clastic sediment packages bounded by thrust faults, and a gently folded shelf sediment cover with strata truncated at the seafloor where uplift is maximal (Figure 4a). Domain III is a $\sim 40-\mathrm{km}$-wide zone showing no evidence of recent contractional brittle features as in the other two domains, but with comparatively longer wavelength deformation. The entire Domain III appears tilted landward including a preexisting extensional basin with rotated blocks overlaid by $\sim 2 \mathrm{~km}$ of landward dipping strata (Figures $4 \mathrm{a}$ and 4c). In Domain III, an indistinct set of subhorizontal reflections at 4-4.5 s two-way traveltime (TWT) define a boundary that might correspond to WAS intrabasement reflector that bounds upper and lower basement sectors with distinct Vp distribution (Figures 3 and 4). However, the reflections in the MCS image are somewhat deeper than the WAS boundary converted to TWT (Figure S6), which might be due to velocity anisotropy. In Domain III, landward dipping, comparatively lower-frequency, semicontinuous reflections abut at the base of the intrabasement reflection, extending seaward to the top of the basement in Domain II (Figure 4a).

Well-layered strata cover the overriding plate across the continental shelf until the middle slope, where the strata lose continuity and the top of basement is indistinct (Figure 4). A basement high located between km 55 and 67 along profile separates two sediment basins. Both basins show different sedimentary architecture and associated deformation. Three main unconformities separate sedimentary units, with truncations and onlaps more pronounced at Domain III (Figure 4c). In Domains II and III, the sedimentary layers dip landward (Figures 4a and 4c), while Domain I strata dip seaward (Figures 4a and 4b). Between Domains I and II, the location of a paleoslope can be identified by the associated prograding clinoform sequences. Active contractional deformation predominates in the sedimentary cover of Domain II, while in the middle and lower part of the northern basin of Domain III, inactive extensional faults can be identified. Between the middle 
and lower slope, below a segment of rough seafloor, the sediment cover loses its stratified character giving way to a $\sim 10-\mathrm{km}$-wide body with chaotic facies.

The interplate boundary is imaged as a series of variable-amplitude reflections. Their amplitude and continuity changes with depth but can be followed to the end of the line near the coastline ( 97 km; Figure 4). Around $10 \mathrm{~km}$ landward of the trench axis and coinciding with a change in the seafloor dip above, the plate boundary is imaged by a series of thin, low-amplitude reflections (Figure 4). Below the uppermost slope and outer continental shelf at Domain I the amplitude, lateral continuity and number of reflections that image the interplate boundary increase progressively with depth. At Domain II, between 58 and $65 \mathrm{~km}$ along the profile, an area of strong lateral velocity gradient probably reflects a highly fractured transitional zone. From km 65 to 78 of Domain III, the plate boundary reflections gradually increase in amplitude and continuity with depth, until they intersect the upper-plate intrabasement reflector, where they abruptly weaken and loose continuity remaining inconspicuous to the end of the line (Figure 4a).

The sediment-basement and the interplate boundaries are clearly imaged in the MCS profile (Figure 4) and in agreement with the inverted WAS reflections (Figure S6), except between $\mathrm{km} 34$ and 43, where there is a mismatch of $0.3 \mathrm{~s}$ TWT between the interplate WAS reflectors (which arrive earlier) and the MCS image. This mismatch occurs underneath the shallow, gently dipping imbricated thrusts within the upper plate. Between Domains I and II, from km 45 to 55 the interplate WAS reflections arrive $0.5 \mathrm{~s}$ TWT later than in the MCS image and the sediment WAS reflector is disrupted. This coincides with the presence of a body of low seismic velocity in the upper plate (Figure 3). A possible explanation for the WAS/MCS traveltime misfit can be seismic anisotropy caused by oriented upper plate structure including a fracture fabric, as postulated for a similar relationship in Nicaragua (Sallarès et al., 2013). In the case of Domain I, the subhorizontal propagation of WAS long-offset phases should occur at lower velocities than near-vertical propagation in the limited-offset MCS records.

The upper $\sim 2$-s TWT or $\sim 4 \mathrm{~km}$ of the basement of the subducting plate displays discontinuous, lowamplitude reflections interbedded with some high-amplitude more continuous reflections (Figure 4). The lower oceanic crust image is poorly defined and masked by multiple energy, but a horizon at $\sim 6-7 \mathrm{~s}$ TWT agrees with the reflector interpreted as the Moho in the WAS profile (Figures 4 and S6).

\section{Discussion}

The discussion section is structured in three parts. First, we interpret the seismic and tectonic structure of the overriding plate, starting with the basement under the slope and outer shelf at Domain I, and continuing with the basement under the shelf of Domains II and III. Then, we use the features of the MCS profile to correlate the three main tectonic phases undergone by the margin with the structural evolution of the upper plate and the sedimentary record. Subsequently, we interpret the structure of the subducting plate. Next, we discuss the potential role of the interplate geometry and the physical properties of the overriding plate on the nucleation of seismic events. We compare the distribution on the cross section of the relocated seismicity of the 1999 Mw 6.9 Quepos and 2002 Mw 6.4 Osa earthquakes and aftershocks, with the tectonic stresses and brittle deformation estimated from a 3-D numerical model (Ruh et al., 2016) constrained to the geometry obtained with the seismic data. Lastly, we compare our results with previous studies in the region.

\subsection{Tectonic Structure and Physical Properties of the Overriding Plate}

Three domains in the overriding plate (Figure 5) have distinctive features in the velocity model (Figure 3) and MCS profile (Figure 4). Domain I contains the frontal $~ 8-\mathrm{km}$-wide sediment prism described in other areas of the MAT (e.g., Bangs et al., 2016; Ranero et al., 2007; Ranero \& von Huene, 2000; von Huene et al., 2000) and in Nicaragua (Ranero et al., 2000; Sallarès et al., 2013; Walther et al., 2000). The 8-km-wide prism along the toe of the slope is imaged (Figures $4 \mathrm{a}, 4 \mathrm{~b}$, and 5 ) as a body of semitransparent facies with a few weak, landward dipping reflections. Interpretation of the 3-D seismic volume has supported that the prism is formed by imbrication of sediments scraped off the incoming trench sequence and covered by slope material deposited on top of the prism (Bangs et al., 2016). This interpretation is partially supported by drilling Site 1412 results (Figures 2 and 4) (Harris et al., 2013), where coring recovered trench sediment layers at the base of the prism that also contained reworked slope sediment. Between the lower and middle slope, marked by rough seafloor (Figure 4b) and with a relative low velocity (Figure 3), a landslide has been 


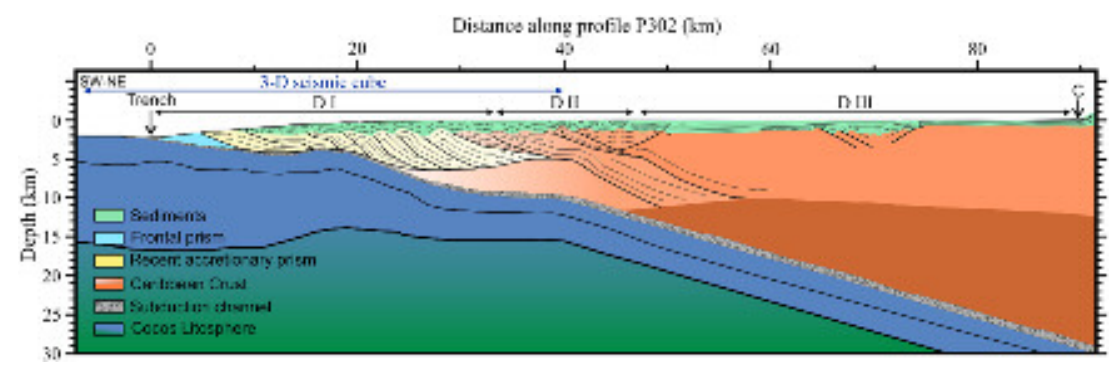

Figure 5. Long-term geological evolution model showing the units that make up the margin of southern Costa Rica. C: coastline; D: Domain; Smt.: Seamount. Blue arrow shows projection of the 3-D seismic cube location (Bangs et al., 2016). $\mathrm{VE} \approx 0.75$

interpreted based on its chaotic character. The main surface of rupture, as well as the surface of separation and some normal faults are identified in MCS data (Figure 4b).

Landward, the MCS profile shows packages of parallel, semicontinuous landward dipping reflections possibly bounded by thrust faults (Figures $4 \mathrm{a}, 4 \mathrm{~b}$, and 5 ). These imbricate stacked layered sequences form a faultpropagation fold geometry, which is mimicked by the sedimentary cover at the middle and upper slope (e.g., CDP 4,500 along profile of Figures 4a and 4b). Bangs et al. (2016) show the along-margin geometry of the imbricate thrust sequences with a 3-D seismic volume acquired in the proximity of our profiles (see location in Figure S1). These authors interpret continuous shortening and thickening of the imbricated body during slope sequence deposition that may still be active, although recent deformation is comparatively minor. The relatively low velocities characteristic of this domain (Figure 3) may be explained by the presence of thrustbounded imbricate sheets of fractured clastic material. These fractures are potential conduits for fluid migration from the subduction interface to the seafloor, possibly causing rock alteration. Ranero et al. (2008) propose a fracture-dominated hydrogeological system across the overriding plate along the Costa Rica and Nicaragua margins. They suggest that fluid contained in the sediment pores and liberated by early dehydration reactions, drain from the interplate boundary to the seafloor through the fractures in the upper plate. Kluesner et al. (2013) detected 161 sites of potential seafloor fluid seepage on the shelf and slope regions based on high-resolution bathymetry and a 3-D seismic grid (see location of the 3-D volume in Figure S1).

The basement of Domain II shows velocities ranging between 4.5-5.5 km/s (Figure 3) with seismic images of long $(>15 \mathrm{~km})$ and thick $(>1 \mathrm{~km})$ landward dipping reflection packages across much of the basement (Figure 4). These discontinuous packages project updip, and deformation is focused in the shelf sediment and seafloor, implying that they may be bound by large thrust faults. The packages have velocities of $\sim 4.7-5.5 \mathrm{~km} / \mathrm{s}$ indicating that - although layered-they are highly indurated rocks with low porosity. The fracture-associated anisotropy proposed for Domain I is no longer visible in Domain II (Figure 4). Domain III does not show shortening-related features or indication of major thrust faulting, but it appears dominated by flexure, possibly indicating accumulating elastic deformation. Tilted basement blocks and normal faults indicate a previous phase of extension. The continuous, medium-amplitude reflector identified at 4-4.5 s TWT in the MCS profile (Figure 4) might be the boundary between the upper- and lower-crust inverted based on WAS data (Figures 3 and S6). Below the intrabasement reflector, the $6.3-\mathrm{km} / \mathrm{s}$ and $6.7-\mathrm{km} / \mathrm{s}$ velocity is typical of lower crust (Figure 3).

The deeply rooted, landward dipping broad package of reflections described across Domain II may extend down to the intrabasement reflector in Domain III (Figures 4 and 5). These packages are possibly bounded by two major tectonic structures, causing active uplift of the sedimentary cover (Figures 4 and 5). These tectonic structures across the upper plate may be responsible for the uplift of Domain II and flexural tilt of Domain III. The discrete deformation structures of the sedimentary cover and the location of the paleoslope inferred from the location of the associated prograding clinoform sequences together support the interpretation of active deformation associated with the landward dipping reflectors. This deformation results in the uplift and seaward migration of the shelf edge (Figure 4). In contrast, the sediment cover layers of Domain I dip seaward, and thrust sheets are interpreted as made of clastic material, either from a past accretionary event or related to reworking of forearc sediment (Bangs et al., 2016). This evidence suggests that 
thin-skinned deformation style with thrust packages rooting in the decollement occurs in Domain I, while thick-skinned tectonics with faults cutting crystalline basement deforms Domains II and III (Figures 4 and 5).

Images of the nearby 3-D seismic volume have been used by Vannucchi et al. (2016) to argue that the imbricated unit is formed by terrigenous clastic strata deposited in a forearc that has been subsequently removed from below by subduction erosion. In the most extreme scenario, these authors propose that the entire forearc can be removed by a single subduction erosion event followed by depositionary replacement without involving transfer of sediments from the incoming plate. Thus, the margin would have grown by deposition of clastic material coming from the continent that replace previous forearc "basement" removed by basal tectonic erosion to keep the wedge from becoming subcritical and deforming (Vannucchi et al., 2016). This "depositionary forearc" model of southern Costa Rica is however based on the observations of the frontal $\sim 30 \mathrm{~km}$ of the margin (i.e., fundamentally Domain I in our data), but the model had not accounted for the physical properties and structure of the entire $\sim 100-\mathrm{km}$-wide margin from the trench to the coastline. The 4.5- to $5.5-\mathrm{km} / \mathrm{s}$ velocity of the Domain II basement and $5.5-6.5 \mathrm{~km} / \mathrm{s}$ of Domain III support the idea that the bulk of the margin is composed of highly consolidated material (Domain II) and possibly crystalline rocks (part of Domain II and Domain III) rather than a clastic terrigenous sediment recently deposited and poorly consolidated (Figures 2, 3, and 5). The most likely interpretation for Domains II and III is that they represent the offshore continuity of the basement material cropping out in Osa Peninsula (i.e., the Osa Mélange) (Vannucchi et al., 2006).

A sediment cover of variable thickness overlays the continental shelf extending to the middle slope. Three main unconformities exist in the sedimentary cover of Domains I and III (Figure 4), but it is in the northern sedimentary basin at Domain III where onlaps and truncations are more evident (Figure 4c). It appears unlikely that the unconformities at both domains are the same, since the history of the northern basin could be substantially different and older than sediments at Domain I. The correlation between unconformities of both segments of the margin is unfeasible since they are eroded at Domain II, where uplift is maximal. The three unconformities of Domain I agree with those interpreted by Edwards, Kluesner, Silver, Brodsky, et al. (2018) across the 3-D seismic cube and reflect the three recent tectonic phases undergone by the region, which were described by Vannucchi et al. (2013) based on the paleodepth record of the Pleistocene sediments recovered during IODP Expedition 334 at Sites U1379 and U1378 (Figures 2 and 4). These authors relate the uplift of the forearc basin from deep water to nearshore conditions ( $\sim 800 \mathrm{~m})$ at early Pleistocene ( 2.3 Ma) with the arrival of the Cocos Ridge at the trench, while they connect the onset of the Cocos Ridge subduction later in the early Pleistocene (from 2.2 to $1.9 \mathrm{Ma}$ ) with high erosional rates at the base of the overriding plate that triggered net subsidence of $\sim 1,200 \mathrm{~m}$. Finally, they interpret the second pulse of uplift $(\sim 1,000 \mathrm{~m})$ from the middle-late Pleistocene to Holocene (from 1.9 Ma to present day) that interrupted subsidence, as the direct effect of the subduction of the thickened Cocos Ridge crust. In contrast, Edwards, Kluesner, Silver, and Bangs (2018) suggest that vertical motions of the outer forearc are a summation of plate to plate changes (e.g., the southeastward Panama Fracture Zone triple-junction migration) and episodic events (e.g., subducting plate relief), rather than a result of a particular continuous process (i.e., this would not be linked to the Cocos Ridge impact with the trench nor its continued subduction) (Morell et al., 2019). Our seismic images extend further landward than the 3-D volume and support large-scale crystallinebasement-involved thick-skinned tectonics, which leads to uplift of seafloor and tilting of the entire forearc basin, possibly a late pulse of uplift related to the Cocos Ridge rather than smaller subducting relief like seamounts or plateaus.

\subsection{The Cocos Ridge Subduction}

No sediment refractions are identified on the subducting Cocos Plate, indicating that it is sediment starved. This is in agreement with results at IODP Site U1381 (Figures 2 and 4), where a thin (96 m) cover of recent to Middle Miocene sediments was recovered (Vannucchi et al., 2013). The velocity model (Figure 3) reflects the high degree of complexity of the Cocos Ridge structure in terms of crustal thickness and bathymetric relief, as is the case of all structures generated by the interaction between the Galapagos hotspot and the CocosNazca spreading center (e.g., Sallarès et al., 2001, 2003). In the case of our profile, crustal thickness decreases sharply from $14 \mathrm{~km}$ below the trench axis to 6-7 km below the continental shelf, reflecting that the WAS profile is oblique to the Cocos Ridge and covers the northwestern flank of the ridge where crustal 


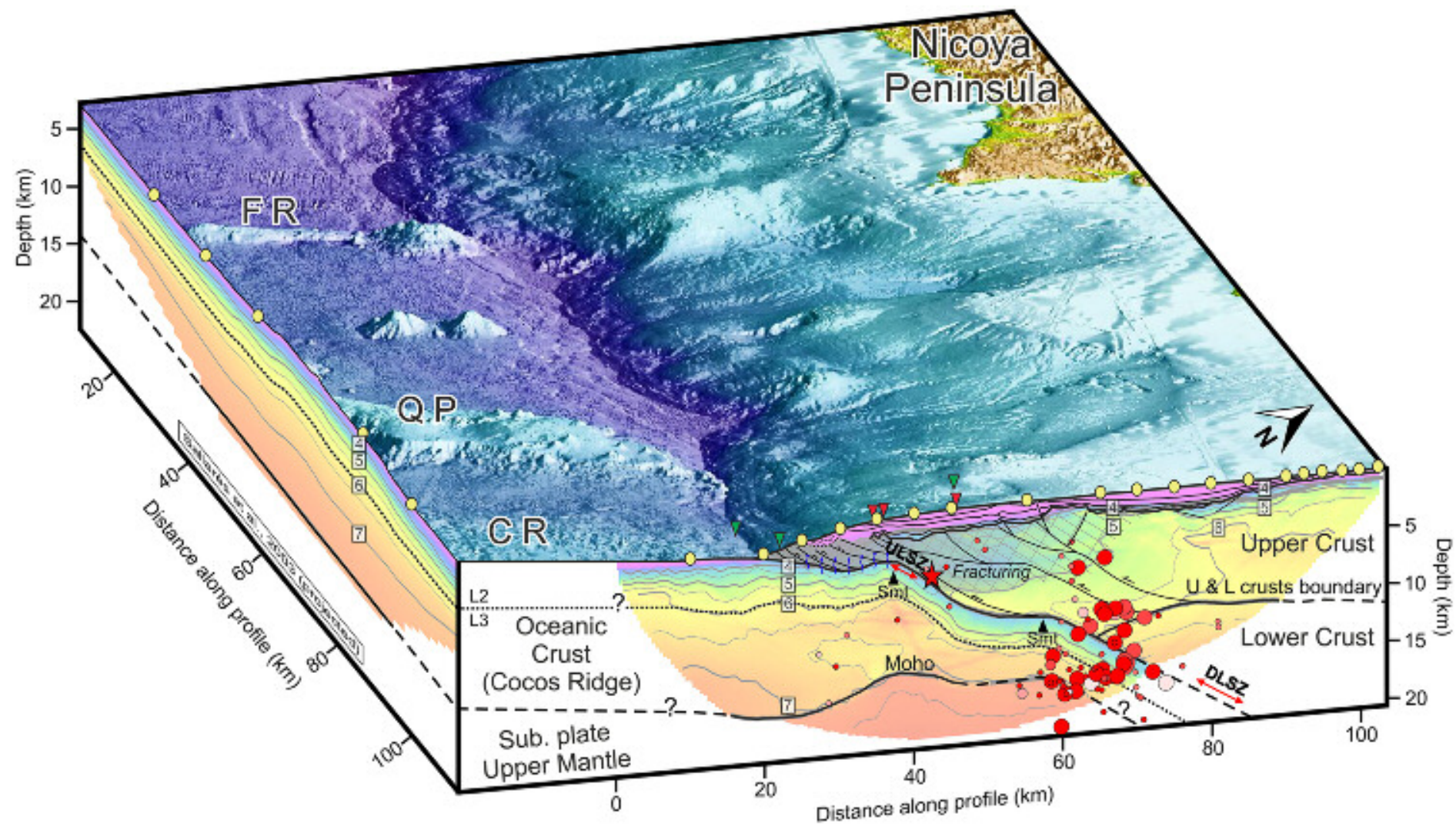

Figure 6. Interpretative cross section of the tectonic and seismic structure along the WAS and MCS profiles at the southern Costa Rica margin, correlated with the bathymetry. Location of the 2002 Osa earthquake (red star) and aftershocks (see legend in Figure 7) from Arroyo, Grevemeyer, et al. (2014). Blue arrows represent fluid migration from the subduction interface to the seafloor. A portion of the along-strike Profile 2 (Figure 5) published by Sallarès et al. (2003) acquired close to our profiles is projected for reference. Note the excellent fit between both velocity models and inverted reflectors (i.e., L2-L3 and Moho boundaries). CR: Cocos Ridge; FR: Fisher Ridge; QP: Quepos Plateau; Smt: Seamount. VE $\approx 0.75$.

thinning is the sharpest (Figures 2, 3, and 5) (e.g., Sallarès et al., 2003; 2005; Walther, 2002, 2003). Our data indicate that the Cocos Ridge represents an aseismic ridge structure, as described in previous works (Sallarès et al., 2003; 2005; Stavenhagen et al., 1998; Walther, 2002, 2003). The Cocos Ridge is divided into two layers corresponding to a thickened oceanic Layer 2 , characterized by a strong vertical velocity gradient $\left(0.65 \mathrm{~s}^{-1}\right)$, $\mathrm{Vp}$ ranging between 3.5 and $6.5 \mathrm{~km} / \mathrm{s}$, and by a uniform thickness of $3.5 \pm 0.5 \mathrm{~km}$; and oceanic Layer 3 , with more uniform $\mathrm{Vp}$ (6.5 to $7.2 \mathrm{~km} / \mathrm{s}$ ) and a highly variable thickness, ranging from a thickened and hence hot spot-affected Layer 3 of $9 \mathrm{~km}$ at the trench axis to more normal values of 3-4 km below the shelf. Therefore, this layer mostly accommodates the crustal overthickening. Under the crust-mantle reflector velocity ranges from 7.0. to $7.8 \mathrm{~km} / \mathrm{s}$, which is similar to the velocity underlying the Quepos Plateau. Comparably low mantle velocities are also imaged at the outer flank of the Cocos Ridge, where it has been attributed to remnants of mafic material in the upper mantle or a plume signature (Walther, 2003).

Both velocity structure and crustal thickness of the subducting Cocos Ridge agree with results obtained by Sallarès et al. (2003) along two WAS profiles acquired perpendicular to the Cocos Ridge, one of them very close to our profile (Figure 6); by Walther (2002, 2003) and Stavenhagen et al. (1998) along four profiles acquired along and across the Cocos Ridge using forward modeling; and by Zhu et al. (2010) along four WAS profiles acquired in the central Costa Rica margin. These authors observe maximum crustal thickness of 16.5-18.5 km beneath the crest of the ridge, which sharply decreases toward the adjacent oceanic basins to 7-8 km thick, similar to that of a normal oceanic crust (e.g., Grevemeyer et al., 2018). Our results are also in agreement with Moho depths obtained by Lücke (2014) based on gravity data along the Middle American Trench. Furthermore, it has to be taken into account that our profile is perpendicular to the trench (i.e., it crosses the Cocos Ridge obliquely to the subduction direction). Therefore, our profile partly shows the thickened crust of the Cocos Ridge and partly the "normal" crust of the adjacent oceanic basin (Figure 2). 


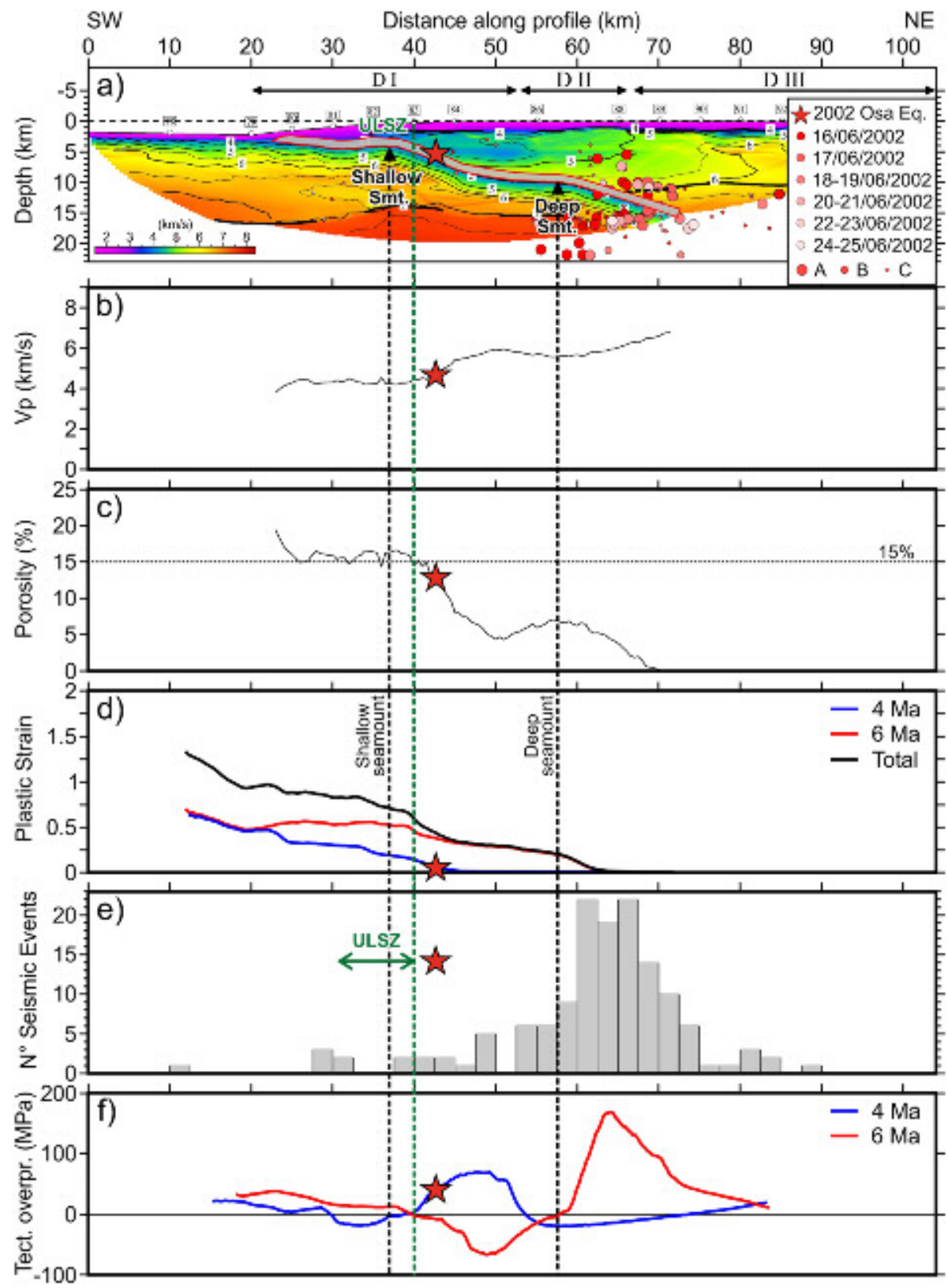

Figure 7. (a) The 2002 Osa earthquake (red star) and aftershocks (colored dots) relocated by Arroyo, Grevemeyer, et al (2014) on top the velocity model (Figure 3). Hypocenters projected from $10 \mathrm{~km}$ to each side of the profile. The aftershocks labels are based on the temporal sequence and the relocation quality (see Arroyo, Grevemeyer, et al., 2014, for detailed information). Average velocity (b) and porosity (c) along a 1.5-km-thick band just above the interplate boundary, as a function of the distance from the trench. To convert velocity into porosity, we have applied an empirical relationship based on data compilation (Nur et al., 1998). Note that error bars are negligible since uncertainty is always $<0.25 \mathrm{~km} / \mathrm{s}$. The dashed black line labels $15 \%$ of porosity as a reference. Crustal deformation (d) and stresses distribution (f) extracted from a high-resolution 3D numerical experiment (see Figure S7; Ruh et al., 2016). Considering that our data set shows two subducting seamounts with $\sim 20-\mathrm{km}$ distance, we have selected two-model time-slices after 4-Ma and 6-Ma runtimes (blue and red lines, respectively). Aftershocks histogram (e), as a function of the distance from the trench. ULSZ: Updip Limit of the Seismogenic Zone.

Our data set shows two remarkable convex-shaped irregularities of the interplate geometry at $\sim 37 \mathrm{~km}$ and $\sim 57 \mathrm{~km}$ along profile, which we interpret to represent subducting seamounts or ocean plate relief (Figures 3, 4, and 6). In the first case, the seamount is located just below a change in seafloor dip at 
the upper slope between OBS/Hs 82 and 84 . These features can be identified in the velocity structure by an increase in the vertical velocity gradient (Figure 3), and a decrease of the reflectivity and lateral continuity of the interplate reflections in the MCS image (Figure 4). The seamounts are aligned parallel to the profile, which is oblique to the direction of subduction and hence, their "subducting paths" are different.

\subsection{Relationship Between Subducting Relief, Upper Plate Deformation, and Earthquake Nucleation}

The seismogenic zone corresponds to the area where the subducting and overriding plates are mechanically coupled. It has been inferred in some works that the updip limit of the seismogenic zone (ULSZ) corresponds to the transition from stable to unstable slip along the subduction megathrusts (Moore \& Saffer, 2001), but experimental data indicate that slip behavior is rate-dependent (e.g., di Toro et al., 2011), so that it is not feasible to define the USLZ based on static parameters for slip. It is commonly assumed that mechanical coupling at the ULSZ is determined by pressure and temperature-dependent processes that take place at temperature above $100-150{ }^{\circ} \mathrm{C}$ such as diagenetic transformations (Hyndman \& Wang, 1993), fault zone cementation, porosity reduction, dehydration, or consolidation of the subducted sediments (e.g., Moore et al., 2007). Fluid abundance may alternatively be a major influence for the change to seismogenic behavior along the subduction interface (Bangs et al., 2015; Ranero et al., 2008). The major production of fluid at $<150$ ${ }^{\circ} \mathrm{C}$ and its efficient expulsion from the interplate boundary fault by fracture permeability causes intergrain contacts to increase with depth raising effective stress and mechanical coupling along the fault. At the same time, the upper plate increases in coherency and has enough thickness to store elastic strain that will be released during earthquakes.

Along the northern and central Costa Rica margin, the interseismic interplate seismicity extends downward from $\sim 15-\mathrm{km}$ depth and follows the $100-120^{\circ} \mathrm{C}$ isotherms along the plate interface (Arroyo, Husen, \& Flueh, 2014; DeShon et al., 2006; Newman et al., 2002). However, at the southern Costa Rica margin offshore Osa it extends downward from 5-km depth (Arroyo, Grevemeyer, et al., 2014; Ranero et al., 2008). To investigate the seismogenic zone in the southern Costa Rica margin, we have compared the structure and interplate geometry with the location of the Mw 6.4 2002 Osa Earthquake sequence, which occurred in the vicinity of our profile (Figure S1). The 2002 Osa sequence was recorded by the National Costa Rica terrestrial network and an OBS network (Arroyo, Grevemeyer, et al., 2014) (Figures 6, 7, and S1). Considering the wavelength of the 3-D geological structure, we projected on our profile only the hypocenters of the 2002 Osa sequence located in a 10-km-wide band on each side of the transect. The distribution of the aftershocks is often used to define the approximate area of rupture of the main shock, which for medium-magnitude events might indicate the approximate extension of the seismogenic zone (Figures 6, 7a, 7e, and S1). The main shock nucleated along the plate boundary, at the leading flank of the shallowest seamount, at $\sim 23$ $\mathrm{km}$ from the trench and at $\sim 6-\mathrm{km}$ depth (Figures 6, 7, and S1). This location is shallower and $\sim 10 \mathrm{~km}$ closer to the trench than other events of comparable magnitude occurred in the central margin of Costa Rica and $\sim 30 \mathrm{~km}$ seaward of other earthquakes nucleated in the northern segment of the margin (e.g., Arroyo, Grevemeyer, et al., 2014; Arroyo, Husen, \& Flueh, 2014). Based on previous studies, the interplate temperatures at the nucleation depth of the Osa event are $100-150{ }^{\circ} \mathrm{C}$ (Harris et al., 2010; Ranero et al., 2008). These temperatures occur at considerably shallower depths than in northern and central Costa Rica. This variation in the location of the ULSZ along the margin might reflect a major change in the geological structure along the subduction zone. Our data set shows that the 2002 Osa Earthquake nucleated where the thick Cocos Ridge crust enters the subduction zone (Figures 6 and 7). Here, the shallow subduction angle of the thick young (warm) crust may bring materials and processes involved in seismogenesis to comparatively shallower depths (Ranero et al., 2008).

The imbricate thrust system of Domain I imaged in the first $\sim 20 \mathrm{~km}$ from the trench along the MCS profile (Figures 4a, 4b, 5, and 6) might act as fluid flow paths, liberating overpressured fluids from the compacting subducting sediment and the accreted strata zone. Further down along the subduction system, the temperature increase to $>100{ }^{\circ} \mathrm{C}$ provides additional fluids from dehydration reactions that have been imaged as the band of plate boundary reflections (Bangs et al., 2015; Ranero et al., 2008). In agreement, numerous seafloor seepage sites document fluid expulsion (Kluesner et al., 2013). 
To determine the properties of the upper plate just above the interplate boundary, we extracted Vp of a $1.5-\mathrm{km}$-thick band at the base of the upper plate (Figure 7b). Then, we have estimated the porosity $(\phi)$ (Figure 7c) using existing empirical relationships (e.g., Mukerji et al., 1995) and assuming that the bulk porosity represents a combination of grain scale porosity and fracture porosity, which decrease as sediment compact and due to active deformation that will tend to focus fluid flow. The relatively higher $\phi$ of the first $15 \mathrm{~km}$ of Domain I ( $\mathrm{km} \mathrm{20-35)} \mathrm{possibly} \mathrm{indicate} \mathrm{the} \mathrm{presence} \mathrm{of} \mathrm{high} \mathrm{porosity} \mathrm{clastic} \mathrm{material}$ and its gradual landward compaction. Further landward, Domain II has $4.5-$ to $5.5-\mathrm{km} / \mathrm{s}$ velocities that indicate highly indurated material so that compaction has expelled most pore water and that $\phi$ may be dominated by fracture porosity (Ranero et al., 2008). Variations in $\phi$ above the interplate boundary are not linear. The shallowest of the subducting seamounts is located at the edge of Domain I where there is an abrupt landward $\phi$ decrease (Figure 7$)$. The high porosity $(\phi>15 \%)$ of most of Domain I suggests that this upper plate sector may not be able to accumulate elastic energy (Figure 7c) (Nur et al., 1991, 1998; Sallarès \& Ranero, 2005). The comparison of our velocity model with the location of the 2002 Osa earthquake suggests that there is a causal link between seamount subduction, upper plate strength and earthquake nucleation.

We integrate these observations with numerical results to evaluate the effects of seamount subduction on tectonic overpressure and brittle strain along the interplate boundary. The numerical experiment is equivalent to the reference model of Ruh et al. (2016) that was established to mimic seamount subduction along the Costa Rica margin (see detailed information about the model set up in the supplementary material). The 3-D numerical modeling tests the evolution of crustal deformation and stress distribution within the upper plate during the indentation of seamounts (Figure S7). We extracted brittle strain and tectonic overpressure from the numerical experiment along a line $1.5 \mathrm{~km}$ above the interplate boundary perpendicular to the trench axis and above the subducting seamount. This has been done for four profiles, corresponding to four model time slices after 4, 5, 6, and $7 \mathrm{Ma}$ (Figure S7). Considering the two subducting seamounts imaged $20 \mathrm{~km}$ apart along the interplate boundary, we assume that the two-model time slices at 4 and 6 Ma represent the conditions at the two subducting seamounts (20-km separation assuming $1-\mathrm{cm} /$ year convergence rate) so that we relate the first time slice to the shallow seamount and the second time slice to the deep seamount (Figures 7d, 7f, and S7). The numerical modeling results show the following: First, brittle deformation increases from the base of leading flank of the seamount to its top, with maximum values from the apex of the seamounts trenchward, indicating that the indenting seamount strongly deforms the overriding plate (Figure 7d). Second, subducting seamounts impose overpressure at their leading flank and underpressure in their trenchward flank (Figure 7f). The location of the Mw 6.4 Osa earthquake at the leading flank of the shallow seamount occurs with moderate brittle deformation/fracturing along the base of the overriding plate, whereas tectonic overpressure is the highest. Both factors appear to be appropriate for earthquake nucleation and could explain the tendency of some shallow megathrust earthquakes to nucleate at the leading flank of subducting seamounts (e.g., 1992 Nicaragua event; McIntosh et al., 2007; Sallarès et al., 2013). Additionally, the porosity degree (possibly fractured dominated) at the main shock nucleation site is below $15 \%$, theoretically allowing stress accumulation and release. These support that nucleation and seismic slip occurred at $\sim 20 \mathrm{~km}$ from the trench and at $\sim 5-\mathrm{km}$ depth in this segment of the margin (Figures 6 and 7). This shallow location is possibly aided by the fact that the subducting seamount exerts on local stresses, supporting that in these circumstances seamount subduction promotes earthquake nucleation.

The relocations of Arroyo, Grevemeyer, et al. (2014) support that the aftershocks following the Mw 6.4 2002 Osa earthquake were distributed in four main clusters (Figures 6, 7a, 7e, and S1), two related to those observed for the Mw 6.91999 Quepos Earthquake but extended few kilometers updip, which originated at the plate interface or in the oceanic crust (Bilek et al., 2003; DeShon et al., 2003). Selected hypocenters from a 10-km-wide band on each side of our velocity model (Figures 6, 7a, 7e, and S1) when projected show that most of them nucleated on the leading flank of the deep seamount. Similarly, the 1999 Quepos sequence has been related to the subducted Quepos Plateau and associated seamounts (Bilek et al., 2003).

Numerical modeling results (Figures 7d and 7f) and (fracture) porosity estimations (Figure 7c) support that aftershocks following Mw 6.42002 Osa earthquake mainly nucleated some $20 \mathrm{~km}$ downdip (Figures 7a and 7e), where deformation at the base of the overriding plate is minor (Figure 7d) and where tectonic overpressure reaches maximum values at the leading flank of the deeper seamount (Figure 7f). Numerical results 
furthermore show that maximum deformation is concentrated at the trenchward flank (Figure 7d), where porosity values also evidence highest (fracture) porosity degree (Figure 7c).

\section{Conclusions}

The integration of the velocity model with the MCS image provides constraints on the nature and geometry of the rock bodies and tectonic structure of the overriding and subducting plates along the southern Costa Rica margin. The distribution of seismic velocity, internal geometry of the different units, and tectonic structure define three domains in the overriding plate:

- Domain I (the sediment prism): a 33-km-wide zone including an 8-km-wide imbricated sediment frontal prism and thin-skinned deformation of an imbricated-thrust system possibly made of clastic rocks with pervasive fault deformation. Vp typically increases landward from $\sim 1.8$ to $<4.5 \mathrm{~km} / \mathrm{s}$, indicating ongoing sediment compaction.

- Domain II: A sector of indurated rocks (Vp 4.5-5.5 km/s) with >15-km-long landward dipping reflection packages possibly indicating intrabasement large-scale thrust faulting that projects updip to a folded and faulted shelf sediment cover with uplifted strata truncated at the seafloor.

- Domain III: a $>$ 9-km-thick and 40-km-wide upper plate sector with velocity $>5 \mathrm{~km} / \mathrm{s}$ across most of it. The Domain does not show recent brittle deformation and appears dominated by regional tilting and possibly elastic deformation. Thick-skinned tectonics of Domain II may cause the uplift of Domain III.

The subducting Cocos Ridge crust displays considerable changes in structure with an abrupt thinning from $14 \mathrm{~km}$ below the trench axis to 6-7 km below the continental shelf. The crustal-seismic structure shows an Upper Layer 2 characterized by high-velocity gradients and constant thickness and a Lower Layer 3 with more uniform velocities that mainly accommodates the thickening of the crust.

The Mw 6.4 2002 Osa earthquake and its aftershocks nucleated at the leading flank of two subducting seamounts. Three-dimensional numerical modeling suggests that earthquakes nucleated where the highest tectonic overpressure locally occurs. Maximum values of brittle strain are concentrated at the trenchward flank of the subducting seamounts, where the highest porosity values support local fracturing reflecting damage caused by the incoming plate relief. Subducting seamounts and associated increased upper plate fracturing, brittle strain, and tectonic overpressure appear colocated with earthquake nucleation, supporting a causal link. These analyses support the conclusion that the seismicity and the structural-mechanical evolution of the upper plate reflects the downward propagation of the leading edge of subducting plate roughness. The Mw 6.4 2002 Osa event occurred at the interplate $\sim 20 \mathrm{~km}$ from the trench axis, at $\sim 5-\mathrm{km}$ depth on the leading flank of a subducting seamount.

This research was supported by E-FIRE (PCIN-2015-053) and FRAME (CTM2015-71766-R) projects, as well as the People Programme (Marie Curie Actions) under REA Grant Agreement 604713 (ZIP "Zooming In between Plates"). The authors dedicate this work to the memory of Kirk McIntosh, without him this paper would not exist. S. M. L. acknowledges financial support through the Juan de la Cierva program. We thank Editor Taylor Schildgen, Don Fisher, and an anonymous reviewer for helpful suggestions and comments. Grateful thanks are also due to the captain, crew, scientific party and technical staff on board the $\mathrm{R} / \mathrm{V}$ Maurice Ewing during the TICOSECT cruise. This work was carried out within the Grups de Recerca de la Generalitat de Catalunya B-CSI (2017 SGR 1662). Several figures were prepared with Generic Mapping Tools (Wessel \& Smith, 1991). Data are available at the PANGAEA world data center (https://doi.org/10.1594/ PANGAEA.909047)

\section{References}

Abratis, M., \& Wörner, G. (2001). Ridge collision, slab-window formation, and the flux of Pacific asthenosphere into the Caribbean realm. Geology, 29(2), 127-130. https://doi.org/10.1130/0091-7613(2001)029<0127:RCSWFA > 2.0.CO;2

Arroyo, I. G., Alvarado, G. E., \& Flueh, E. R. (2003). Local seismicity at the Cocos Ridge-Osa Peninsula Subduction Zone, Costa Rica, Abstract S52F-0174.

Arroyo, I. G., Grevemeyer, I., Ranero, C. R., \& von Huene, R. (2014). Interplate seismicity at the CRISP drilling site: The 2002 Mw 6.4 Osa Earthquake at the southeastern end of the Middle America Trench. Geochemistry, Geophysics, Geosystems, 15, 3035-3050. https://doi. org/10.1002/2014GC005359

Arroyo, I. G., Husen, S., \& Flueh, E. R. (2014). The seismogenic zone in the Central Costa Rican Pacific margin: High-quality hypocentres from an amphibious network. International Journal of Earth Sciences (Geol Rundsch), 103(7), 1747-1764. https://doi.org/10.1007/ s00531-013-0955-8

Bangs, N. L., McIntosh, K. D., Silver, E. A., Kluesner, J. W., \& Ranero, C. R. (2015). Fluid accumulation along the Costa Rica subduction thrust and development of the seismogenic zone. Journal of Geophysical Research - Solid Earth, 120, 67-86. https://doi.org/10.1002/ 2014JB011265

Bangs, N. L., McIntosh, K. D., Silver, E. A., Kluesner, J. W., \& Ranero, C. R. (2016). A recent phase of accretion along the southern Costa Rican subduction zone. Earth and Planetary Science Letters, 443, 204-215. http://doi.org/10.1016/j.epsl.2016.03.008

Barckhausen, U., Ranero, C. R., von Huene, R., Cande, S. C., \& Roeser, H. A. (2001). Revised tectonic boundaries in the Cocos Plate off Costa Rica: Implications for the segmentation of the convergent margin and for plate tectonic models. Journal of Geophysical Research, 106(207-19), 220. https://doi.org/10.1029/2001JB000238

Bilek, S. L., Schwartz, S. Y., \& DeShon, H. R. (2003). Control of seafloor roughness on earthquake rupture behavior. Geology, 31(5), 455-458. https://doi.org/10.1130/0091-7613(2003)031<0455:COSROE > 2.0.CO;2

Cloos, M., \& Shreve, R. L. (1996). Shear-zone thickness and the seismicity of Chilean- and Marianas-type subduction zones. Geology, 24(2), 107-110. https://doi.org/10.1130/0091-7613(1996)024<0107:sztats >2.3.co;2 
DeMets, C. (2001). A new estimate for present-day Cocos-Caribbean plate motion: Implications for slip along the Central American volcanic arc. Geophysical Research Letters, 28, 4043-4046. https://doi.org/10.1029/2001gl013518

DeShon, H. R., Schwartz, S. Y., Bilek, S. L., Dorman, L. M., Gonzalez, V., Protti, J. M., et al. (2003). Seismogenic zone structure of the southern Middle America Trench, Costa Rica. Journal of Geophysical Research, 108(B10), 2491. https://doi.org/10.1029/2002JB002294

DeShon, H. R., Schwartz, S. Y., Newman, A. V., Gonzalez, V., Protti, M., Dorman, L. M., et al. (2006). Seismogenic zone structure beneath the Nicoya Peninsula, Costa Rica, from three-dimensional local earthquake P- and S-wave tomography. Geophysical Journal International, 164(1), 109-124. https://doi.org/10.1111/j.1365-246X.2005.02809.X

Di Toro, G., Han, R., Hirose, T., De Paola, N., Nielsen, S., Mizoguchi, K., et al. (2011). Fault lubrication during earthquakes. Nature, 471, 494-498. https://doi.org/10.1038/nature09838

Dzierma, Y., Rabbel, W., Thorwart, M. M., Flueh, E. R., Mora, M. M., \& Alvarado, G. E. (2011). The steeply subducting edge of the Cocos Ridge: Evidence from receiver functions beneath the northern Talamanca Range, south-central Costa Rica. Geochemistry, Geophysics, Geosystems, 12, Q04S30. https://doi.org/10.1029/2010GC003477

Edwards, J. H., Kluesner, J. W., Silver, E. A., \& Bangs, N. L. (2018). Pleistocene vertical motions of the Costa Rican outer forearc from subducting topography and a migrating fracture zone triple junction. Geosphere, 14(2), 510-534. https://doi.org/10.1130/GES01577.

Edwards, J. H., Kluesner, J. W., Silver, E. A., Brodsky, E. E., Brothers, D. S., Bangs, N. L., et al. (2018). Corrugated megathrust revealed offshore from Costa Rica. Nature Geoscience, 11(3), 197-202. https://doi.org/10.1038/s41561-018-0061-4

Fisher, D. M., Gardner, T. W., Sak, P. B., Sanchez, J. D., Murphy, K., \& Vannucchi, P. (2004). Active thrusting in the inner forearc of an erosive convergent margin, Pacific coast, Costa Rica. Tectonics, 23, TC2007. https://doi.org/10.1029/2002TC001464

Flueh, E. R., \& Bialas, J. (1996). A digital, high data capacity ocean bottom recorder for seismic investigations. International Underwater Systems Design, 18, 18-20.

Gardner, T. W., Verdonck, D., Pinter, N. M., Slingerland, R., Furlong, K. P., Bullard, T. F., \& Wells, S. G. (1992). Quaternary uplift astride the aseismic Cocos Ridge, Pacific Coast, Costa-Rica. Geological Society of America Bulletin, 104, 219-232. https://doi.org/10.1130/00167606(1992)104<0219:quatac >2.3.co;2

Grevemeyer, I., Ranero, C. R., \& Ivandic, M. (2018). Structure of oceanic crust and serpentinization at subduction trenches. Geosphere, 14(2), 395-418. https://doi.org/10.1130/GES01537.1

Harris, R. N., Sakaguchi, A., Petronotis, K., \& the Expedition 344 Scientists (2013). Proceedings Integrated Ocean Drilling Program (Vol. 344). College Station, TX: Ocean Drill. Program. https://doi.org/10.2204/iodp.sp.344.2012

Harris, R. N., Spinelli, G., Ranero, C. R., Grevemeyer, I., Villinger, H., \& Barckhausen, U. (2010). Thermal regime of the Costa Rican convergent margin: 2. Thermal models of the shallow Middle America subduction zone offshore Costa Rica. Geochemistry, Geophysics, Geosystems, 11, Q12S29. https://doi.org/10.1029/2010GC003273

Hey, R. (1977). Tectonic evolution of the Cocos-Nazca spreading center. Geological Society of America Bulletin, 88, 1414-1420. https://doi. org/10.1130/0016-7606(1977)88<1404:teotcs>2.0.co;2

Husen, S., Kissling, E., \& Quintero, R. (2002). Tomographic evidence for a subducted seamount beneath the Gulf of Nicoya, Costa Rica: The cause of the 1990 Mw57.0 Gulf of Nicoya earthquake. Geophysical Research Letters, 29(8), 1238. https://doi.org/10.1029/ 2001GL014045

Hyndman, R. D., \& Wang, K. (1993). Thermal constraints on the zone of major thrust earthquake failure-The Cascadia subduction zone. Journal of Geophysical Research, 98, 2039-2060. https://doi.org/10.1029/92jb02279

Hyndman, R. D., Yamano, M., \& Oleskevich, D. A. (1997). The seismogenic zone of subduction thrust faults. Island Arc, 6, 244-260. https:// doi.org/10.1111/j.1440-1738.1997.tb00175.x

Kimura, G., Silver, E., Blum, P., \& Party, S. S. (1997). Proceedings of the Ocean drilling Program, Initial Rep. (Vol. 170). College Station, TX. Ocean Drill. Program.

Kluesner, J. W., Silver, E. A., Bangs, N. L., McIntosh, K. D., Gibson, J., Orange, D., et al. (2013). High density of structurally controlled, shallow to deep water fluid seep indicators imaged offshore Costa Rica. Geochemistry, Geophysics, Geosystems, 14, 519-539. https://doi. org/10.1002/ggge.20058

Kolarsky, R. A., Mann, P., \& Montero, W. (1995). Island arc response to shallow subduction of the Cocos Ridge, Costa Rica. Geological Society of America, 295, 235-262. https://doi.org/10.1130/SPE295-p235

Korenaga, J., Holbrook, W. S., Kent, G. M., Kelemen, P. B., Detrick, R. S., Larsen, H. -C., et al. (2000). Crustal structure of the southeast Greenland margin from joint refraction and reflection seismic tomography. Journal of Geophysical Research, 105, 21,591-21,614. https:// doi.org/10.1029/2000jb900188

Lay, T., Kanamori, H., Ammon, C. J., Koper, K. D., Hutko, A. R., Ye, L., et al. (2012). Depth-varying rupture properties of subduction zone megathrust faults. Journal of Geophysical Research, 117, B04311. https://doi.org/10.1029/2011JB009133

Lücke, O., \& Arroyo, I. G. (2015). Density structure and geometry of the Costa Rican subduction zone from 3-D gravity modeling and local earthquake data. Solid Earth, 6, 1169-1183. https://doi.org/10.5194/se-6-1169-2015

Lücke, O. H. (2014). Moho structure of Central America based on three-dimensional lithospheric density modelling of satellite derived gravity data. International Journal of Earth Sciences, 103(7), 1733-1745. https://doi.org/10.1007/s00531-012-0787-y

Martínez-Loriente, S., Sallarès, V., Gràcia, E., Bartolome, R., Dañobeitia, J. J., \& Zitellini, N. (2014). Seismic and gravity constraints on the nature of the basement in the Africa-Eurasia plate boundary: New insights for the geodynamic evolution of the SW Iberian margin. Journal of Geophysical Research - Solid Earth, 119, 127-149. https://doi.org/10.1002/2013JB010476

McIntosh, K. D., Silver, E., \& Shipley, T. (1993). Evidence and mechanisms for forearc extension at the accretionary Costa Rica convergent margin. Tectonics, 12, 1380-1392. https://doi.org/10.1029/93tc01792

McIntosh, K. D., Silver, E. A., Ahmed, I., Berhorst, A., Ranero, C. R., Kelly, R. K., \& Flueh, E. R. (2007). The Nicaragua convergent margin: Seismic reflection imaging of the source of a tsunami earthquake, Rica. In T. Dixon \& J. C. Moore (Eds.), The seismogenic zone of subduction thrust faults (pp. 257-287). NewYork: Columbia University Press.

Mochizuki, K., Yamada, T., Shinohara, M., Yamanaka, Y., \& Kanazawa, T. (2008). Weak interplate coupling by seamounts and repeating M 7 earthquakes. Science, 321(5893), 1194-1197. https://doi.org/10.1126/science.1160250

Moore, J. C., \& Saffer, D. (2001). Updip limit of the seismogenic zone beneath the accretionary prism of southwest Japan: An effect of diagenetic to low-grade metamorphic processes and increasing effective stress. Geology, 29, 183-186. https://doi.org/10.1130/0091-7613 (2001)029<0183:ULOTSZ>2.0.CO;2.

Moore, J. C., Rowe, C., \& Meneghini, F. (2007). How accretionary prisms elucidate seismogenesis in subduction zones. In T. H. Dixon \& J. C. Moore (Eds.), The seismogenic zone of subduction thrust faults (pp. 288-315). NY: Columbia University Press.

Morell, K. D., Fisher, D. M., \& Bangs, N. (2019). Plio-Quaternary outer forearc deformation and mass balance of the southern Costa Rica convergent margin. Journal of Geophysical Research: Solid Earth, 124. https://doi.org/10.1029/2019JB017986 
Moser, T. J., van Eck, T., \& Nolet, G. (1992). Hypocenter determination in strongly heterogeneous earth models using the shortest path method. Journal of Geophysical Research, 97(B5), 6563-6572. https://doi.org/10.1029/91JB03176

Mukerji, T., Berryman, J., Mavko, G., \& Berge, P. (1995). Differential effective medium modelling of rock elastic moduli with critical porosity constraints. Geophysical Research Letters, 22, 555-558. https://doi.org/10.1029/95gl00164

Newman, A. V., Schwartz, S. Y., Gonzalez, V., DeShon, H. R., Protti, J. M., \& Dorman, L. M. (2002). Along-strike variability in the seismogenic zone below Nicoya Peninsula, Costa Rica. Geophysical Research Letters, 29(20), 1977. https://doi.org/10.1029/ 2002gl015409

Nur, A., Marion, D., \& Yin, H. (1991). Wave velocities in sediments. In J. M. Hoven, M. D. Richardson, \& R. D. Stoll (Eds.), Shear Waves in Marine Sediments (pp. 131-140). New York: Springer.

Nur, A., Mavko, G., Dvorkin, J., \& Galmudi, D. (1998). Critical porosity: A key relating physical properties to porosity in rocks. The Leading Edge, 17, 357-362. https://doi.org/10.1190/1.1437977

Oleskevich, D. A., Hyndman, R. D., \& Wang, K. (1999). The updip and downdip limits to great subduction earthquakes: Thermal and structural models of Cascadia, south Alaska, SW Japan, and Chile. Journal of Geophysical Research, 104(B7), 14,965-14,991. https://doi. org/10.1029/1999JB900060

Ranero, C., Vannucchi, P., \& von Huene, R. (2007). Drilling the seismogenic zone of an Erosional convergent margin: IODP Costa Rica Seismogenesis Project CRISP. In Abstracts and Report From the IODP/ICDP Workshop on Fault Zone Drilling, edited, Special Edition N.1 (pp. 51-54). Miyzaki, Japan: Integrated Ocean Drill. Program Manage. Int.

Ranero, C. R., Grevemeyer, I., Sahling, H., Barckhausen, U., Hensen, C., Wallmann, K., et al. (2008). Hydrogeological system of erosional convergent margins and its influence on tectonics and interplate seismogenesis. Geochemistry, Geophysics, Geosystems, 9, Q03S04. https://doi.org/10.1029/2007GC001679

Ranero, C. R., \& von Huene, R. (2000). Subduction erosion along the Middle America convergent margin. Nature, 404(6779), 748-752 https://doi.org/10.1038/35008046

Ranero, C. R., von Huene, R., Flueh, E. R., Duarte, M., Baca, D., \& McIntosh, K. D. (2000). A cross section of the convergent Pacific margin of Nicaragua. Tectonics, 19, 335-357. https://doi.org/10.1029/1999tc900045

Ranero, C. R., von Huene, R., Weinrebe, W., \& Barckhausen, U. (2007). Convergent margin tectonics of Middle America: A marine perspective. In G. Alvarado, \& J. Bunschu (Eds.), Central America Geology Hazards and Resources (pp. 239-265). A. A. Balkema Publisher.

Ruh, J. B., Sallarès, V., Ranero, C. R., \& Gerya, T. (2016). Crustal deformation dynamics and stress evolution during seamount subduction: High-resolution 3-D numerical modeling. Journal of Geophysical Research: Solid Earth, 121. https://doi.org/10.1002/2016JB013250

Sak, P. B., Fisher, D. M., \& Gardner, T. W. (2004). Effects of subducting seafloor roughness on upper plate vertical tectonism: Osa Peninsula, Costa Rica. Tectonics, 23, TC1017. https://doi.org/10.1029/2002TC001474

Sallarès, V., Dañobeitia, J. J., \& Flueh, E. R. (2000). Seismic tomography with local earthquakes in Costa Rica. Tectonophysics, 329(1-4), 61-78, ISSN 0040-1951. https://doi.org/10.1016/S0040-1951(00)00188-8

Sallarès, V., Charvis, P., Flueh, E. R., \& Bialas, J. (2003). Seismic structure of Cocos and Malpelo Volcanic Ridges and implications for hotspot-ridge interaction. Journal of Geophysical Research, 108(B12), 2564. https://doi.org/10.1029/2003JB002431

Sallarès, V., Dañobeitia, J. J., \& Flueh, E. (2001). Lithospheric structure of the Costa Rican Isthmus: Effects of subduction zone magmatism on an oceanic plateau. Journal of Geophysical Research, 106, 621-643. https://doi.org/10.1029/2000jb900245

Sallarès, V., Melendez, A., Prada, M., Ranero, C. R., McIntosh, K., \& Grevemeyer, I. (2013). Overriding plate structure of the Nicaragua convergent margin: Relationship to the seismogenic zone of the 1992 tsunami earthquake. Geochemistry, Geophysics, Geosystems, 14, 3436-3461. https://doi.org/10.1002/ggge.20214

Sallarès, V., \& Ranero, C. R. (2005). Structure and tectonics of the erosional convergent margin off Antofagasta, north Chile (2330’'S). Journal of Geophysical Research, 110, B0601. https://doi.org/10.1029/2004JB003418

Scholz, C. H., \& Small, C. (1997). The effect of seamount subduction on seismic coupling. Geology, 25(6), 487-490. https://doi.org/10.1130/ 0091-7613(1997)025<0487:teosso >2.3.co;2

Stavenhagen, A. U., Flueh, E. R., Ranero, C., McIntosh, K. D., Shipley, T., Leandro, G., et al. (1998). Seismic wide-angle investigations in Costa Rica-A crustal velocity model from the Pacific to the Caribbean. Zentralblatt fur Geologie und Palaeontologie Teil 1: Allgemeine, Angewandte, Regionale, und Historische Geologie, 3(6), 393-408.

Stoffa, P. L., Shipley, T. H., Dean, D., Kessinger, W., Silver, E., Reed, D., \& Aguilar, A. (1991). Three dimensional seismic imaging of the Costa Rica accretionary prism: Field program and migration examples. Journal of Geophysical Research, 96, 21,693-21,721. https://doi. org/10.1029/91jb02120

Tichelaar, B. W., \& Ruff, L. J. (1993). Depth of seismic coupling along subduction zones. Journal of Geophysical Research, 98, $2017-2037$. https://doi.org/10.1029/92jb02045

Toomey, D. R., \& Foulger, G. R. (1989). Tomographic inversion of local earthquake data from the Hengill-Grensdalur central volcano complex, Iceland. Journal of Geophysical Research, 94, 17,497-17,510. https://doi.org/10.1029/jb094ib12p17497

Vannucchi, P., Fisher, D. M., Bier, S., \& Gardner, T. W. (2006). From seamount accretion to tectonic erosion: Formation of Osa Mélange and the effects of Cocos Ridge subduction in southern Costa Rica. Tectonics, 25, TC2004. https://doi.org/10.1029/2005TC001855

Vannucchi, P., Galeotti, S., Clift, P., Ranero, C. R., \& von Huene, R. (2004). Long term subduction erosion along the Middle America Trench offshore Guatemala. Geology, 32, 617-620. https://doi.org/10.1130/G20422.1

Vannucchi, P., Morgan, J. P., Silver, E. A., \& Kluesner, J. W. (2016). Origin and dynamics of depositionary subduction margins. Geochemistry, Geophysics, Geosystems, 17, 1966-1974. https://doi.org/10.1002/2016GC006259

Vannucchi, P., Ranero, C. R., Galeotti, S., Straub, S. M., Scholl, D. W., \& McDougall-Ried, K. (2003). Fast rates of subduction erosion along the Costa Rica Pacific margin: Implications for nonsteady rates of crustal recycling at subduction zones. Journal of Geophysical Research, 108(B11), 2511. https://doi.org/10.1029/2002JB002207

Vannucchi, P., Sak, P. B., Morgan, J. P., Ohkushi, K. I., Ujiie, K., \& The, I. E. S. S. (2013). Rapid pulses of uplift, subsidence, and subduction erosion offshore Central America: Implications for building the rock record of convergent margins. Geology, 41(9), 995-998. https://doi. org/10.1130/G34355.1

Vannucchi, P., Ujiie, K., Stroncik, N., Malinverno, A., \& the Expedition 334 Scientists (2012). Proceedings of Integrated Ocean Drilling Program (Vol. 334). Tokyo: Ocean Drill. Program Manage. Int., Inc. https://doi.org/10.2204/iodp.proc.334.2012

von Huene, R., Ranero, C. R., \& Vannucchi, P. (2004). Generic model of subduction erosion. Geology, 32(10), 913-916. https://doi.org/ 10.1130/G20563.1

von Huene, R., Ranero, C. R., Weinrebe, W., \& Hinz, K. (2000). Quaternary convergent margin tectonics of Costa Rica, segmentation of the Cocos Plate, and Central American volcanism. Tectonics, 19, 314-334. https://doi.org/10.1029/1999TC001143 
Walther, C. (2002). Crustal structure of the Cocos Ridge northeast of Cocos Island, Panama Basin. Geophysical Research Letters, 29(20), 1986. https://doi.org/10.1029/2001GL014267

Walther, C. H. E. (2003). The crustal structure of the Cocos ridge off Costa Rica. Journal of Geophysical Research, 108(B3), 2136. https://doi. org/10.1029/2001JB000888

Walther, C. H. E., Flueh, E. R., Ranero, C. R., von Huene, R., \& Strauch, W. (2000). Crustal structure across the Pacific margin of Nicaragua: Evidence for ophiolitic basement and a shallow mantle sliver. Geophysical Journal International, 141, 759-777. https://doi.org/10.1046/ j.1365-246x.2000.00134.x

Wang, K., \& Bilek, S. L. (2011). Do subducting seamounts generate or stop large earthquakes? Geology, 39, 819-822. https://doi.org/ $10.1130 / \mathrm{G} 31856.1$

Werner, R., Hoernle, K., van den Bogaard, P., Ranero, C. R., von Huene, R., \& Korich, D. (1999). Drowned 14 m.y. old Galápagos archipelago off the coast of Costa Rica: Implications for tectonic and evolutionary models. Geology, 27, 499-502. https://doi.org/10.1130/00917613(1999)027<0499:dmyogp >2.3.co;2

Wessel, P., \& Smith, W. H. F. (1991). Free software helps map and display data (Vol. 72, p. 441). Washington, DC: Eos

Zhu, J., Kopp, H., Papenberg, C., Klaeschen, D., Flueh, E. R., \& Planert, L. (2010). Margin architecture and seismic attenuation in the central Costa Rican forearc. Marine Geology, 276, 30-41. https://doi.org/10.1016/j.margeo.2010.07.004

\section{References From the Supporting Information}

Gerya, T. (2010). Introduction to numerical geodynamic modelling (p. 345). Cambridge, UK: Cambridge University Press

Gerya, T., \& Yuen, D. A. (2007). Robust characteristics method for modelling multiphase visco-elasto-plastic thermo-mechanical problems. Physics of the Earth and Planetary Interiors, 163(1-4), 83-105. https://doi.org/10.1016/j.pepi.2007.04.015

Tarantola, A. (1987). Inverse problem theory: Methods for data fitting and model parameter estimation. New York: Elsevier Sci. 